\title{
PENGELOLAAN TANAH WAKAF MASJID DI KOTA MANADO
}

\author{
Salim Hasan \\ Kementerian Agama Kota Manado \\ salimhasan140@gmail.com \\ Ahmad Rajafi \\ Institut Agama Islam Negeri Manado, Indonesia \\ ahmad.rajafi@iain-manado.ac.id
}

\begin{abstract}
This article will specifically examine the elements related to the management of Mosque Waqf Land, Manado City, whether it has been functioning as the act or whether the law has not been able to accommodate the problems that occur in the management of waqf land in Manado City. The result is that the management of waqf land in Manado City is classified into two things, namely effective and ineffective. But ineffective is more than effective, this is because many mosque administrators feel that the process of obtaining certificates is very procedural, so they have difficulty managing the certificate. So that, the relavancy is with the enactment of Law Number 41 year 2004 concerning Waqf, the recording of legal waqf acts is obligatory to provide legal protection and legal certainty for wakif, Nazhir and that assets that are represented.
\end{abstract}

Keywords: Management, Mosque Waqf Land, Manado City, Law Number 41 year 2004

Abstrak Artikel ini secara spesifik akan menelaah tentang unsur-unsur yang terkait dalam pengelolaan wakaf tanah masjid di Kota Manado, apakah sudah berfungsi sebagaimana UU tersebut ataukah UU tersebut belum dapat mengakomodir permasalahan-permasalahan yang terjadi dalam pengelolaan wakaf tanah masjid di Kota Manado. Hasilnya adalah, bahwa pengelolaan wakaf tanah masjid di Kota Manado terklasifikasi pada dua hal, yakni efektif dan tidak efektif. Namun yang tidak efektif lebih banyak dari yang efektif, hal ini disebabkan karena banyak pengurus masjid merasa bahwa proses pengurusan sertifikat sangat prosedural, sehingga mereka kesulitan untuk mengurus sertifikat tersebut. Relevenasinya adalah, dengan berlakunya UU No. 41 Tahun 2004 tentang Wakaf, maka pencatatan perbuatan hukum wakaf menjadi wajib hukumnya untuk memberikan perlindungan hukum dan kepastian hukum bagi wakif, Nazhir serta harta yang diwakafkan.

Kata Kunci: Pengelolaan, Tanah Wakaf Masjid, Kota Manado, UU No. 41 Tahun 2004 


\section{Pendahuluan}

Perwakafan atau wakaf merupakan salah satu dari ajaran-ajaran Islam yang mengandung nilai ibadah dan sosial secara bersamaan. Mengandung nilai ibadah karena salah satu dorongan wakaf adalah untuk mencari keridhaan Allah swt dan dikatakan mengandung nilai sosial karena mewakafkan atau memberikan sesuatu kepada orang lain.

Pada aspek keagamaan, wakaf bukan hanya merupakan sedekah biasa, tetapi merupakan sedekah yang memiliki nilai lebih daripada sedekahsedekah lainnya. Sedekah berupa wakaf lebih besar pahala dan manfaatnya bagi orang yang memberikan wakaf, karena harta yang diwakafkan itu akan terusmenerus mengalir pahalanya kepada orang yang memberikan wakaf (wakif) sekalipun ia telah meninggal (shadaqah jariah), selama harta yang diwakafkan itu masih bisa dimanfaatkan. Selain itu, wakaf bisa menjadi jalan dan perantara untuk memajukan agama serta membangun masyarakat dalam berbagai bidang kehidupan.

Wakaf merupakan infrastruktur sosial dan keagamaan (Islam) yang telah lama melembaga sebagai instrument sosial masyarakat. Sebelum lahir Undang-undang Nomor 41 Tahun 2004 tentang Wakaf, di Indonesia pada umumnya wakaf lebih didominasi oleh wakaf tanah yang lebih diorientasikan pada ibadah mahdhah (pokok) seperti untuk pembangunan masjid, mushallah, kuburan, pondok pesantren, madrasah, jalan umum dan sebagainya.

Berkenaan dengan ibadah wakaf tersebut, Islam secara jelas telah mengajarkan kepada seseorang untuk menafkahkan sebagian harta benda miliknya kepada orang lain, baik individu ataupun kolektif. Sebagaimana

1 Departemen Agama RI, Alqur'an dan Tafsirnya (Jakarta: Departemen Agama, 2012) Juz. 4, h. 1.

${ }^{2}$ Ibid. dijelaskan dalam al-Qur'an yang sekaligus menjadi dasar hukum wakaf, seperti dalam QS. Ali Imran, ayat 92 berikut:

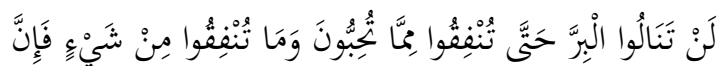

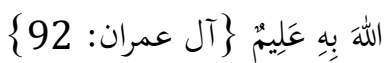

Artinya: "Kamu tidak akan memperoleh kebajikan, sebelum kamu menginfakkan sebagian harta yang kamu cintai. Dan apapun yang kamu infakkan, tentang hal itu sungguh, Allah Maha Mengetahui." (QS. Ali Imran: 92$)^{1}$

Ayat tersebut ditafsirkan oleh Kementerian Agama sebagai petunjuk di mana seseorang tidak akan mencapai tingkat kebajikan di sisi Allah, sebelum ia dengan ikhlas menafkahkan harta yang dicintainya di jalan Allah. Setelah ayat ini diturunkan, para sahabat Nabi berlomba-lomba berbuat kebaikan, di antaranya Abu Talhah al-Ansari, seorang hartawan dikalangan Ansar datang kepada Nabi memberikan sebidang kebun kurma yang sangat dicintainya untuk dinafkahkan di jalan Allah. ${ }^{2}$

dengan adanya pertimbangan bahwa praktik wakaf yang terjadi dalam kehidupan masyarakat belum sepenuhnya berjalan tertib dan efisien sehingga dalam berbagai kasus harta wakaf tidak dipelihara dan dikelola oleh Nazhir sebagaimana mestinya. Keadaan demikian itu tidak hanya karena kelalaian atau ketidakmampuan Nazhir dalam mengelola dan mengembangkan harta benda wakaf tapi karena juga sikap masyarakat yang kurang peduli atau belum memahami status harta benda wakaf yang seharusnya dilindungi demi untuk kesejahteraan umum sesuai dengan tujuan, fungsi, dan peruntukan wakaf. ${ }^{3}$

Berdasarkan hasil pra-research permasalahan yang berkaitan dengan

3 Departemen Agama RI, Undang-Undang Wakaf dan Peraturan Pemerintah Tentang Pelaksanaannya (Jakarta: Departemen Agama RI, 2007) h. 39. 
pengelolaan wakaf tanah khususnya masjid di Kota Manado, dibagi dalam dua klasifikasi yaitu wakaf tanah masjid yang pengelolaannya tidak efektif dan wakaf tanah yang pengelolalaannya efektif, dipaparkan sebagai berikut :

1. Pengelolaan wakaf tanah yang tidak efektif :

a. Wakif atau pemilik harta benda wakaf datang kepada imam atau pengurus masjid untuk mewakafkan tanahnya. Imam atau pengurus mesjid dihadapan PPAIW (kepala KUA) mendaftarkan tanah wakaf yang telah diamanahkan wakif atas namanya. PPAIW menerbitkan Ikrar Wakaf, surat pengesahan Nazhir, Akta Ikrar Wakaf, Akta Pengganti Akta Ikrar Wakaf. Berkas yang sudah siap diusulkan ke BPN untuk diterbitkan sertifikatnya, namun kendalanya sampai sampai saat ini sertifikatnya belum dapat diterbitkan. Kasus ini terjadi di Masjid Al-Qadir Kelurahan Singkil Dua Kecamatan Singkil Kota Manado

b. Ada tanah masjid yang telah bersertifikat wakaf, akan tetapi sebagian lahannya tidak diproduktifkan untuk kepentingan ekonomi umat ataupun biaya operasional masjid. Kasus ini terjadi di Masjid Awal Fathul Mubin Kelurahan Islam Kecamatan Tuminting Kota Manado.

c. Ada tanah masjid yang telah bersertifikat wakaf, akan tetapi dilakukan tukar guling oleh pengurusnya tanpa melalui prosedur menurut Undangundang No.41 Tahun 2004, dengan tanah yang lain bukan wakaf. Kasus ini terjadi di Masjid Nurul Iman kelurahan Singkil Dua Kecamatan Singkil Kota Manado.
2. Pengelolaan wakaf tanah yang efektif:

Masjid Al Misbah bersertifikat wakaf yang letaknya di Kelurahan Singkil Satu Kecamatan Singkil adalah merupakan wakaf tanah masjid yang telah bersertifikat wakaf, sekaligus juga diberdayakan sebagai wakaf produktif dalam membantu keuangan masjid tersebut.

Pada umumnya banyak permasalahan yang terjadi berkaitan dengan pengelolaan wakaf tanah masjid di Kota Manado. Walaupun sudah ada landasan hukumnya dalam pengelolaan wakaf tanah masjid yaitu Undangundang Nomor 41 Tahun 2004 tentang Wakaf. Dengan adanya aturan tersebut apakah masih banyak yang tidak relevan ataupun unsur-unsur yang terkait dalam aturan tersebut yang tidak berfungsi untuk menjalankan tugasnya masingmasing.

Melalui penelitian ini akan melihat unsur-unsur yang terkait dalam pengelolaan wakaf tanah masjid, apakah sudah berfungsi sebagaimana UU tersebut ataukah UU tersebut belum dapat mengakomodir permasalahanpermasalahan yang terjadi dalam pengelolaan wakaf tanah masjid di Kota Manado. Untuk itu unsur-unsur yang terkait dalam pengelolaan tanah wakaf seperti Nazhir, Kepala Kantor Urusan Agama Kecamatan dan Badan Wakaf Indonesia (BWI) yang ada di Kota Manado apakah berfungsi sebagaimana Undang-undang Nomor 41 Tahun 2004 tentang wakaf ataukah ada kendalakendala lainnya sehingga permasalahan wakaf tanah masjid masih terjadi di Kota Manado.

\section{Metode Penelitian}

Jenis penelitian dalam artikel ini adalah evaluasi, yang mengukur atau menilai pelaksanaan program, hasil karya, atau suatu kegiatan yang dilihat dari tolak ukurnya, atau dengan 
membandingkannya dengan tujuan atau sasaran yang telah ditetapkan. ${ }^{4}$

Sedangkan jika dilihat dari sisi jenis datanya, maka penelitian ini merupakan penelitain kualitatif, di mana data dinyatakan dalam bentuk-bentuk simbolik seperti pernyataan-pernyataan tafsiran, tanggapan-tanggapan lisan harfiah, nonverbal, dan grafik-grafik, yang diperoleh dari observasi partisipan, ${ }^{5}$ terhadap masalah atau gejala yang muncul di dalam pola kerja dan kebijakan yang muncul di dalam pengorganisasian wakaf tanah masjid di Kota Manado oleh para pengelola wakaf (nadzir, PPAIW, BWI).

Sifat penelitian ini adalah kualitatif-deskriptif-analitis, maksudnya bahwa dalam penelitian kualitatif data yang dikumpulkan bukan berupa angka, melainkan data tersebut berasal dari wawancara, norma-norma hukum, catatan lapangan, catatan memo dan dokumen resmi lainnya, ${ }^{6}$ yang ada pada nadzir PPAIW dan BWI di wilayah Kota Manado dengan tujuan untuk mendeskripsikan secara sistematis, faktual dan akurat terhadap suatu populasi atau daerah tertentu, mengenai sifat-sifat, karakteristik-karakteristik atau faktor-faktor tertentu, ${ }^{7}$ yakni masalah pengorganisasian wakaf tanah masjid di Kota Manado.

Adapun data diperoleh dengan menggunakan teknik wawancara mendalam, observasi terhadap program dan implementasi program oleh para pengelola wakaf yakni Nadzir, PPAIW dan BWI dalam mengorganisasi wakaf tanah masjid di Kota Manado, serta dokumentasi di dalamnya.

Selanjutnya, pengolahan data melalui proses pengumpulan data,

4 Lihat Tatang M. Amirin, Menyusun Rencana Penelitian, (Jakarta: Rajawali Press, 1986), Cet. I, h. 109

${ }^{5}$ Ibid., h. 119 reduksi data, display data, dan penarikan kesimpulan. Dengan proses tersebut diharapkan dapat memberikan kesimpulan yang didukung dengan data yang sesuai. Data-data tersebut berkaitan dengan pengelolaan wakaf tanah implementasi penerapan Undangundang Nomor 41 Tahun 2004, khususnya penerapan wakaf tanah masjid di Kota Manado.

\section{Pengelolaan Wakaf Tanah Masjid di Kota Manado}

Perbuatan hukum wakaf di Indonesia telah sudah dikenal semenjak zaman sebelum kemerdekaan Republik Indonesia, pada saat itu orang-orang Indonesia yang beragama Islam jauh sebelum kemerdekaan telah melaksanakan perwakafan. Hal tersebut dikarenakan pada saat itu di Indonesia sudah banyak berdiri kerajaan-kerajaan Islam seperti Demak dan Samudra Pasai dan lain-lain.

Perkembangan wakaf di Indonesia dapat dikatakan sejalan dengan perkembangan penyebaran Islam. Pada masa-masa awal penyiaran Islam, kebutuhan terhadap masjid untuk menjalankan aktivitas ritual dan dakwah berdampak positif, yakni pemberian tanah wakaf untuk mendirikan masjid menjadi tradisi yang lazim dan meluas di komunitas-komunitas Islam di Nusantara.

Seiring dengan perkembangan sosial masyarakat Islam dari waktu ke waktu praktik perwakafan mengalami kemajuan setahap demi setahap. Tradisi wakaf untuk tempat ibadah tetap bertahan dan mulai muncul wakaf lain untuk kegiatan pendidikan seperti untuk pendirian pesantren dan

6 Lexi. J. Moloeng, Metode Penelitian Kuantatif, (Bandung: Remaja Rosda Karya, 2002), h. 3-4

7 Bambang Sunggono, Metode Penelitian Hukum, (Jakarta: Raja Grafindo Persada, 2001), h. 36 
madrasah. Dalam periode berikutnya, corak pemanfaatan wakaf terus berkembang, sehingga mencakup pelayanan sosial kesehatan, seperti pendirian klinik dan panti asuhan.

Secara umum orang lebih mengenal istilah wakaf hanya untuk orang muslim (orang yang beragama Islam), keberadaan wakaf di Indonesia adalah digunakan untuk masjid, musholla, sekolah, rumah, jariyah, tanah pertanian, yatim piatu. Pemanfaatan tersebut dilihat dari segi sosial khususnya untuk kepentingan peribadatan memang efektif, tetapi dampaknya kurang berpengaruh positif dalam kehidupan ekonomi masyarakat. Apabila peruntukan wakaf hanya terbatas pada hal-hal di atas tanpa diimbangi dengan wakaf yang dikelola secara produktif, maka kesejahteraan sosial ekonomi masyarakat yang diharapkan dari lembaga wakaf, tidak akan dapat terealisasi secara optimal.

Di masa pertumbuhan ekonomi di Indonesia yang cukup memprihatinkan saat ini, sesungguhnya peranan wakaf di samping instrumen-instrumen ekonomi Islam lainnya seperti zakat, infaq, sedekah dan lain-lain belum dapat dirasakan manfaatnya untuk meningkatkan taraf hidup masyarakat khususnya di bidang ekonomi. Dalam impelementasi wakaf tersebut di dalam masyarakat, paling tidak ada beberapa macam shigat dalam wakaf masjid: ${ }^{8}$

1. Sebidang tanah diwakafkan menjadi masjid, seperti perkataan wakif; "Aku jadikan tempat ini sebagai masjid." Dengan perkataan wakif seperti ini, menurut pendapat yang kuat hukumnya secara langsung tanah yang dimaksud menjadi masjid meskipun tidak terdapat bangunan masjid, sehingga hamparan tanah itu

${ }^{8}$ Lebih lanjut lihat Ibnu Hajar al-Haitami, Tuhfah al-Muhtaj bi Syarh al-Manhaj, Cet. II (Beirut: Dar al-Kutub al-'Ilmiyah, 2005) h. 428 diberlakukan hukum masjid, seperti haram bagi yang berhadats besar berdiam di tempat itu, sah i'tikaf, sunnah shalat tahiyyatul masjid dan lain-lain. Dengan demikian masjid tidak harus berbentuk fisik bangunan, meskipun berupa hamparan tanah kosong, jika oleh pemiliknya dijadikan masjid dengan shighot sebagaimana diatas, maka sah hukumnya. Oleh karena seluruh hamparan tanah tersebut statusnya langsung berubah menjadi masjid, maka pemanfaatan tanah tersebut secara keseluruhan harus difungsikan masjid, dan tidak boleh ada bagian tanah yang difungsikan untuk selain masjid, misalnya dibangun toilet, kantor dan lainlain.

2. Wakaf tanah agar dibangun masjid. Berbeda dengan bagian pertama, wakaf model ini, wakif tidak menjadikan tanah yang dimaksud sebagai masjid, tetapi dimaksudkan agar di atas tanah itu dibangun masjid. Dengan demikian tanah yang diwakafkan tidak serta merta menjadi masjid, akan tetapi statusnya sebagai tanah wakaf yang disyaratkan oleh wakif agar dibangun masjid. Wakaf model ini memungkinkan pembangunan fisik masjid sesuai dengan model masjid yang berlaku saat wakaf. Artinya, hamparan tanah itu tidak harus seluruhnya dibangun fisik masjid, dan boleh dibangun beberapa fasilitas pendukung masjid menurut yang berlaku pada saat itu, seperti kamar mandi, toilet, halaman dan lain-lain.

3. Wakaf bangunan menjadi masjid. Artinya tanah dan bangunan yang sudah jadi, diwakafkan menjadi 
masjid, baik bangunan tersebut model masjid atau tidak. Wakaf masjid model ini menjadikan tanah dan bangunan menjadi masjid setelah shighot wakaf diucapkan.

4. Menghimpun dana untuk pembangunan masjid di atas lahan kosong yang bukan berstatus masjid. Artinya, uang atau barang yang terkumpul dari penyumbang digunakan untuk pembangunan masjid. Wakaf masjid model ini tidak memerlukan shighot. Karena bangunan yang berdiri dari hasil sumbangan itu dengan sendirinya berlaku hukum masjid meskipun tidak terdapat shighot wakaf dari penyumbang maupun pengurus masjid, sebab setiap bahan material bangunan yang sudah terpasang dalam bangunan fisik masjid dengan sendirinya menjadi masjid. Adapun uang atau barang yang terkumpul dan dibelanjakan untuk pembangunan sarana penunjang masjid, seperti kamar mandi dan lain-lain, tidak dihukum masjid, sebab pada saat penarikan sumbangan, masing-masing penyumbang sudah dapat memahami bahwa uang atau material yang terkumpul dari para penyumbang tidak hanya dialokasikan untuk biaya pembangunan fisik masjid, tetapi juga untuk sarana penunjang lainnya. Dengan demikian pengurus pembangunan masjid boleh menggunakan sebagian dari sumbangan yang terkumpul untuk pembangunan sarana penunjang masjid berdasarkan kerelaan dari penyumbang yang dapat diketahui dari kebiasaan yang berlaku dalam pembangunan masjid.

Atas dasar petunjuk di atas, maka jika ada bangunan dengan model masjid, namun tidak diketahui secara pasti siapa pembangunnya, apakah dibangun di atas tanah tak bertuan (ardl al-mawat) atau tanah milik, dan apakah yang membangunnya telah melafadzkan shighat wakaf atau tidak, maka diberlakukan hukum-hukum masjid atas bangunan tersebut, baik telah masyhur di kalangan masyarakat penyebutan masjid atau tidak.

\section{Grafik 1}

\section{Jumlah Tanah Wakaf di Kota Manado} Tahun 2017

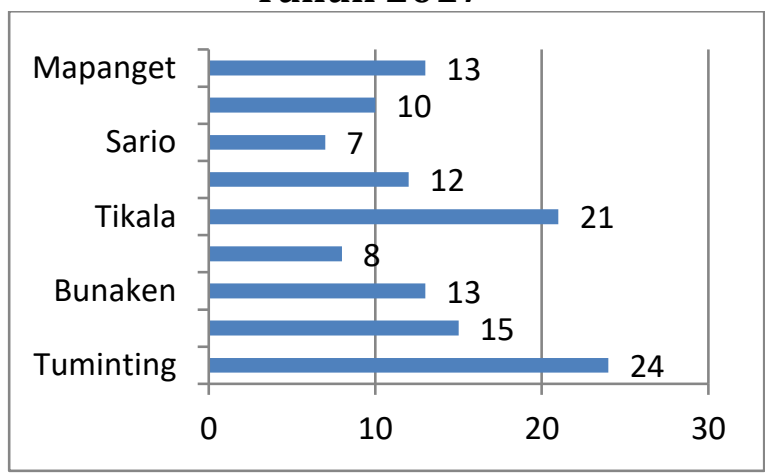

Sumber: Data Kementerian Agama Kota Manado Tahun 2017

Data di atas menunjukkan bahwa jumlah tanah wakafdi Kec. Mapanget sebanyak 13 lokasi, Malalayang 10 lokasi, Sario 7 lokasi, Wanea 12 lokasi, Tikala 21 Lokasi, Wenang 8 lokasi, Bunaken 13 lokasi, Singkil 15 lokasi, dan Tuminting 24 lokasi. Dari data tersebut yang terbanyak adalah di Kecamatan Tuminting dan yang terendah yaitu di Kecamatan Sario.

\section{Grafik 2}

Status Tanah Wakaf di Kota Manado

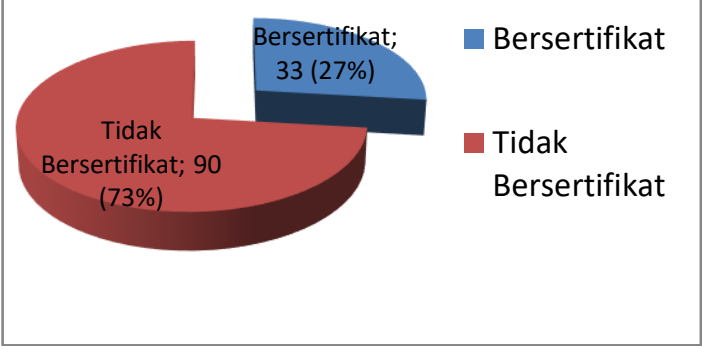

Sumber: Data Kementerian Agama Kota Manado Tahun 2017 
Data di atas menunjukkan bahwa status tanah wakaf di Kota Manado yang sudah bersertifikat berjumlah 33 (27\%) dan yang belum bersertifikat berjumlah 90 (73\%). Hal ini menunjukkan masih banyak tanah wakaf yang belum bersertifikat.

Adapun pengelolaan wakaf yang selama ini berjalan di Kota Manado masih banyak yang menggunakan pola manajemen pengelolaan yang terhitung tradisional dan konsumtif. Hal tersebut dapat diketahui melalui beberapa aspek, diantaranya yaitu:

1. Kepemimpinan:

Corak kepemimpinan dalam lembaga kenazhiran masih bersifat sentralistik-otoriter (paternalistik) dan tidak ada sistem yang memadai.

2. Rekuitmen SDM Kenazhiran: Banyak nazhir wakaf yang hanya didasarkan pada aspek ketokohan seperti imam, bukan pada aspek profesionalisme atau kemampuan dalam mengelola. Sehingga banyak benda-benda wakaf yang tidak terurus atau terkelola dengan baik.

3. Operasionalisasi Pemberdayaan: Pola yang digunakan lebih kepada sistem yang tidak jelas (tidak memiliki standar operasional) karena lemahnya SDM, visi dan misi pemberdayaan, dukungan political will pemerintah yang belum maksimal dan masih menggunakan sistem ribawi.

4. Pola Pemanfaatan Hasil: Dalam menjalankan upaya pemanfaatan hasil wakaf masih banyak yang bersifat konsumtif-statis sehingga kurang dirasakan manfaatnya oleh masyarakat banyak.

5. Sistem Kontrol Dan Pertanggung Jawaban: Sebagai resiko dan pola kepemimpinan yang sentralistik dan lemahnya operasionalisasi pemberdayaan mengakibatkan pada lemahnya sistem kontrol, baik yang bersifat kelembagaan, pengembangan usaha maupun keuangan. ${ }^{9}$

Pola manajemen pengelolaan tanah wakaf seperti tersebut di atas sangat kental sekali atau banyak sekali terjadi di daerah-daerah dalam Kota Manado. Karena masyarakat pada umumnya, apabila melakukan perbuatan wakaf maka mereka lebih mempercayakan kepada imam setempat untuk dijadikan nazhir. Karena masyarakat umum beranggapan bahwa imam sebagai tokoh agama tersebutlah yang lebih tahu atau mumpuni dalam hal wakaf padahal belum tentu.

Sebagai lembaga keagamaan yang berkecimpung dalam bidang sosial, sudah sepatutnya wakaf untuk dikelola secara produktif dan profesional, baik itu wakaf bergerak ataupun wakaf tidak bergerak. Dikatakan sebagai tanah wakaf produktif yaitu apabila tanah wakaf tersebut mampu menghasilkan sesuatu, dimana dari hasil tanah wakaf tersebut dapat digunakan untuk memakmurkan masjid, menyantuni fakir miskin ataupun yang lainnya. Biasanya tanah wakaf produktif tersebut berbentuk sebuah tanah pertanian yang subur, pertokoan, perusahaan dan kegiatan-kegiatan lainnya yang lebih mengarah kepada bidang perekonomian.

Agar tanah wakaf produktif tersebut terus berkembang dan lebih maju maka perlu adanya sebuah pengelolaan yang profesional dan modern. Sifat profesionalisme ini digambarkan dalam al-Qur'an surat alIsra' ayat 84:

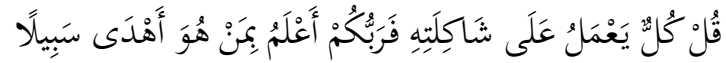

$$
\begin{aligned}
& \text { \{84: الإسرآئ }
\end{aligned}
$$


Artinya: "Katakanlah, tiap-tiap orang berbuat menurut keadaannya masingmasing maka Tuhanmu lebih mengetahui siapa yang lebih benar jalannya." (QS. alIsra': 84)

Ayat tersebut mengemukakan bahwa setiap orang beramal dan berbuat sesuai dengan kemampuan. Artinya seseorang harus bekerja dengan penuh ketekunan dengan mencurahkan keahliannya. Jika seseorang bekerja sesuai dengan kemampuannya, maka akan melahirkan hal-hal yang optimal. ${ }^{10}$ Dalam hal ini sebuah pengelolaan dikatakan profesional dan modern itu dapat dilihat pada aspek-aspek pengelolaannya, diantaranya yaitu: ${ }^{11}$

1. Kelembagaan.

Untuk mengelola benda-benda wakaf secara produktif, yang pertamatama harus dilakukan adalah perlunya pembentukan suatu badan atau lembaga yang khusus mengelola wakaf yang ada. Badan ini diberikan tugas untuk mengembangkan wakaf secara produktif sehingga wakaf dapat berfungsi untuk meningkatkan taraf hidup masyarakat. Badan wakaf ini juga secara organisatoris harus bersifat independen, dimana pemerintah dalam hal ini sebagai fasilitator, regulator, motivator dan pengawasan. Tugas utama badan ini adalah memberdayakan wakaf, baik wakaf benda tidak bergerak maupun benda bergerak, sehingga dapat memberdayakan ekonomi umat.

2. Pengelolaan Operasional

Yang dimaksud dengan standar operasional pengelolaan wakaf adalah batasan atau garis kebijakan dalam mengelola wakaf agar menghasilkan sesuatu yang lebih bermanfaat bagi kepentingan masyarakat banyak. Standar keputusan operasional merupakan tema pokok dalam operasi kelembagaan nadhir yang ingin

10 Didin Hafidudin dan Hendri Tanjung, Manajemen Syari'ah Dalam Praktek (Jakarta: Gema Insani Press, 2003) h. 63 mengelola secara produktif. Keputusan yang dimaksud di sini berkenaan dengan lima fungsi utama manajemen operasional, yaitu: ${ }^{12}$

a. Proses, keputusan mengenai proses termasuk proses fisik berkenaan dengan fasilitas yang akan dipakai untuk memproduksi barang atau jasa. Karena itu, sangat penting untuk menyerasikan antara proses fisik dan strategi pemberdayaan produktif terhadap benda-benda wakaf dalam jangka panjang.

b. Kapasitas, keputusan mengenai kapasitas diperlukan untuk menghasilkan jumlah produk yang tepat, di tempat yang tepat dan dalam waktu yang tepat pula.

c. Sediaan, keputusan berkaitan dengan sediaan ini mencakup apa yang akan dipesan, berapa banyak dan kapan dipesan.

d. Tenaga kerja, pengelolaan SDM merupakan hal yang sangat penting dalam operasional lembaga kenadhiran, mengingat tidak ada sesuatu yang dapat diselesaikan tanpa SDM yang mencukupi.

e. Mutu, salah satu fungsi terpenting dari bagian operasi adalah bertanggung jawab atas mutu barang atau jasa yang dihasilkan.

3. Kehumasan

Dalam mengelola benda-benda wakaf, maka peran kehumasan (pemasaran) dianggap menempati posisi penting. Fungsi dari kehumasan itu sendiri dimaksudkan untuk:

a. Memperkuat image bahwa benda-benda wakaf yang dikelola oleh nazhir profesional

11 Ibid., h. 106-113

12 Wawancara dengan PPAIW Kota Manado tanggal 15 Agustus Tahun 2017 
betul-betul

dikembangkan

dapat

untuk

dan hasilnya

kesejahteraan

masyarakat banyak.

b. Meyakinkan kepada calon wakif yang masih ragu-ragu apakah benda-benda yang ingin diwakafkan dapat dikelola secara baik atau tidak.

a. Memperkenalkan aspek wakaf yang tidak hanya berorientasi pada pahala oriented, tapi juga memberikan bukti bahwa ajaran Islam sangat menonjolkan aspek kesejahteraan bagi umat manusia lain, khususnya kalangan yang kurang mampu.

\section{Sistem Keuangan}

Penerapan sistem keuangan yang baik dalam sebuah proses pengelolaan manajemen lembaga kenazhiran sangat terkait dengan:

a. Akuntansi, pada awalnya akuntansi lebih diwarnai dan relatif terbatas pada aspek pertanggung jawaban belaka. Namun dalam perkembangannya, akuntansi mengalami transformasi sebagai salah satu sumber informasi dalam pengambilan keputusan bisnis. Ini membawa konsekuensi, misalnya pada bentuk kandungan laporannya. Bila dalam tahapan awal ada penekanan yang lebih pada aspek neraca, misalnya kemudian beralih pada aspek laba rugi.

b. Auditing, adalah bahwa pihak pelaksana melaporkan neraca terbuka tugas atau amanah yang diberikan kepadanya, dan pihak yang memberikan

13 Kasus di Kel. Malendeng Kec. Paal Dua, Wawancara dengan Pejabat Struktural di Kantor Kementerian Agama Kota Manado Tanggal 14 Agustus Tahun 2017 amanah mendengarkan. Jadi ini merupakan manifestasi pertanggung jawaban pihak tertentu yang diberi tanggung jawab kepada pihak yang memberi amanah.

Dalam hal ini ternyata masih banyak tanah-tanah wakaf untuk masjid yang jauh dari idelitas profesional dalam pengelolaannya. Seperti status tanah yang akan diwakafkan tidak jelas, wakifnya telah meninggal, wakifnya non muslim, Nazhirnya sebagian ataupun seluruhnya sudah meninggal, Nazhirnya tidak proaktif mengurus wakaf. Nazhir yang ditunjuk oleh wakif SDM-nya kurang sehingga tidak memahami tugas dan tanggungjawabnya, sehingga pengelolaannya diambil alih BTM. ${ }^{13}$

Permasalahan lainnya yaitu kurang aktifnya pihak yang terkait dalam pensertifikatan wakaf tanah misalnya KUA sebagai PPAIW, Wakif, Nazhir, BWI, dan Pemerintah sebagaimana masalah tukar guling wakaf tanah di Masjid Nurul Iman Kelurahan Singkil Dua. BWI tidak memiliki data Nazhir yang akurat dan lengkap disebabkan kurangnya alokasi dana baik dari DIPA Kementerian Agama Kota Manado maupun dari Pemerintah Daerah. Untuk mengatasi hal tersebut BWI bersama Seksi Bimas Islam Melaksanakan pendataan, sosialisasi dan pembinaan kepada Nazhir, PPAIW, dan Ormas Islam. ${ }^{14}$

Adapun di wilayah Ketang Baru, pensertifikatan wakaf tanah Masjid di wilayah KUA Kecamatan mendapat bantuan dana dari DIPA Kantor wilayah Kementerian Agama Provinsi Sulawesi Utara. Pendataan wakaf tanah dan sosialisasi di KUA Kecamatan dilaksanakan sekaligus pada saat wasrik di KUA Kecamatan. Namun, karena

14 Wawancara dengan Pejabat Struktural di Kantor Kementerian Agama Kota Manado Tanggal 14 Agustus Tahun 2017 
kurang proaktifnya Nazhir dalam pengurusan pensertifikatan tanah wakaf disebabkan SDM Nazhir tentang tugas dan fungsinya sangat kurang apalagi tidak membaca dan memahami Undangundang Nomor 41 Tahun 2004 tentang wakaf, walhasil hingga saat ini tanah wakaf masjid tersebut belum juga bersertifikat. ${ }^{15}$

Selain daripada itu, kepengurusan BWI Kota Manado yang sudah terbetuk selama 3 tahun, ternyata tidak melibatkan staf Bimas Islam untuk masuk dalam kepengurusan sehinggan sulit untuk koordinasi tentang data wakaf maupun kegiatan sosialisasi dan bimbingan. Data yang diterima dari KUA Kecamatan sebagian besar adalah data yang lama tidak mengalami perubahan sehingga ada tanah wakaf yang baru atau tanah wakaf lama belum bersertifikat wakaf akan disertifikatkan sulit mendapatkan arsipnya karena KUA tidak melampirkan arsip saat mengirim data ke Bimas Islam. Terlebih lagi ternyata kurangnya alokasi dana dalam DIPA baik dari Kantor Kemenag Kota Manado, Kanwil Agama maupun Pemerintah Daerah dalam menunjang kegiatan sosialisasi dan bimbingan. ${ }^{16}$

Untuk wilayah Teling ternyata pengorganisasian tanah wakaf masjid juga tidak efektif. Hal ini karena pengelolaan wakaf tanah masjid yaitu KUA tidak mengusulkan tentang Nazhir yang sudah tidak proaktif maupun sudah meninggal, adanya Nazhir yang tidak mau diganti, kurangnya sosialisasi terhadap Nazhir, seperti di masjid Nurul Iman.

Bahkan kasus yang terbaru adalah, tidak adanya laporan tentang pernah dilakukannya tukar guling tanah wakaf yang dilakukan oleh nazhir, untuk meningkatkan kualitas tanah wakaf menjadi wakaf produktif, dengan

15 Wawancara dengan Imam Masjid Nurul Imam Ketang Baru, Tanggal 11 Agustus Tahun 2017 mengadakan gedung serba guna/gedung pernikahan muslim dengan menggarap wakaf uang. Ketika dilakukan observasi dan wawancara dengan pengurus BWI dijelaskan bahwa Badan wakaf, Pemerintah dan Nazhir telah melengkapi semua berkas administrasi yang berhubungan dengan tukar guling wakaf tanah. Bahkan Bimas Islam selaku sekertaris BWI (Eks oficio) telah mengelola administrasi wakaf tanah kemudian kerjasama dengan ketua dan pengurus dalam pelaksanaan kegiatan yang meliputi pendataan, sosialisasi dan bimbingan serta penyelesaian permasalahan di lapangan. Atas dasar permasalahanpermasalahan tersebut, maka dapat dievaluasi bahwa:

1. Adanya program pemerintah melalui Bimbingan Masyarakat Islam Kementerian Agama Kota Manado melakukan pendataan tanah wakaf di KUA Kecamatan, Sosialisasi dan bimbingan bagi PPAIW (Pejabat Pembuat Akta Ikrar Tanah) dan Nazhir namun tidak berjalan secara efektif.

2. Pemerintah melalui Kemenag Proinsi telah memfasilitasi penyelesaian pensertifikatan wakaf tanah yang belum bersertifikat dengan bantuan anggaran dari DIPA Kantor Wilayah Kementerian Agama Provinsi Sulawesi Utara, namun masih saja ada oknum nazhir yang menyelewengkan dana tersebut untuk kebutuhan di luar kebutuhan sertifikasi tanah wakaf masjid.

3. Seksi Bimas Islam telah melaksanakan pendataan, sosialisasi dan pembinaan kepada Nazhir, PPAIW, dan Ormas Islam, tapi masih pada tataran seremonial. Terbukti setelah sosialisasi,

16 Wawancara staf pelaksana di Kantor Kementerian Agama Kota Manado tanggal 14 Agustus Tahun 2017 
evaluasi terhadap mereka tidak dilakukan sama sekali, bahkan hingga saat ini masih ada masjid yang nazhirnya sudah meniggal cukup lama tapi statusnya sebagai nazhir masih aktif hingga saat ini.

4. Menjadikan wakaf tanah yang punya lahan untuk ditingkatkan menjadi wakaf produktif, dengan cara mengadakan gedung serba guna atau gedung pernikahan muslim dengan menggarap wakaf uang, menggalang masyarakat muslim untuk berwakaf uang. Namun hasil dari observasi, istilah wakaf produktif masih bersifat teoretis sehingga ada nazhir yang tidak mengetahui bagaimana implementasi dari wakaf produktif. Walhasil, pengorganisasian tanah wakaf masjid tidak berjalan dengan baik. Sertifikat wakafnya ada, tapi pengorganisasiannya tidak optimal dan masing sangat tradisional.

5. Kurang aktifnya BWI dalam melaksanakan tugasnya karena kurangnya dukungan dana baik dari DIPA Kementerian Agama Kota Manado maupun dari Pemerintah Daerah, sehingga data yang diterima dari KUA Kecamatan sebagian besar tidak mengalami perubahan, bahkan ada tanah wakaf yang baru atau tanah wakaf lama belum bersertifikat akan disertifikatkan sulit mendapatkan arsipnya karena KUA tidak melampirkan arsip saat mengirim data ke Bimas Islam.

Atas dasar pembacaan data di atas maka dapat dipahami bahwa pengorganisasian wakaf tanah masjid di Kota Manado melalui teori besar berupa evaluasi yang mengarahkan pada kegiatan untuk mengumpulkan informasi tentang perwakafan di Kota Manado dan kemudian informasi tersebut digunakan untuk menentukan alternatif yang tepat ketika mengambil keputusan, menghasilkan dua jawaban, yakni pengelolaan atau pengorganisasian wakaf tanah masjid yang berjalan secara efektif dengan nomina mikro dan yang tidak efektif dengan nomina makro.

Analisis evaluatif tersebut perlu mendapatkan penanganan yang lebih di lapangan dengan menggunakan middle theory yang secara sadar akan menempatkan kehadirannya dalam hubungan erat dengan manusia dan masyarakat. Artinya, penelitian ini secara positif akan mampu mengembangkan pola pengelolaan wakaf yang lebih maju dan progresif dengan menguatkan pembinaan SDM yang profesional sehingga pengorganisasian yang pada awalnya tidak efektif menjadi efektif, dan yang sudah efektif menjadi percontohan bagi yang belum efektif.

Hukum progresif secara selektif akan menguatkan pada ranah administrasi berupa sertifikasi tanah wakaf dan selanjutnya pembinaan SDM. Pembinaan SDM juga bukan sekedar bersandar pada norma hukum yang berlaku di dalam masyakarat, tapi juga mampu meretas kehendak dan respon masyarakat setempat dan selanjutnya melahirkan model pengelolaan dan pengorganisasian wakaf tanah masjid yang produktif dan berkemajuan, dengan petunjuk utama:

1. Wakaf tanah masjid tersebut mempunyai tujuan besar berupa kesejahteraan dan kebahagiaan manusia.

2. Pengorganisasi wkat tanah masjid tersebut mampu memuat kandungan moral kemanusiaan yang sangat kuat.

3. Penguatan pemahaman para pengelola wakaf tanah masjid yang sinergi antara teori wakaf yang tidak hanya bergerak pada ranah praktik melainkan juga teori.

4. Bersifat kritis dan fungsional. 
Olah pikir yang berkemajuan tersebut sejalan dengan teori terapan dalam penelitian ini yang secara khusus menilai dari jalur kemaslahatan (almas\}lah\}ah) dengan artian yakni menarik dan mewujudkan kemanfaatan atau menyingkirkan dan menghindari kemudaratan (jalb manfa >'ah atau daf'u mad\}arrah) dengan jalan memelihara agama, jiwa, akal budi, keturunan, dan harta kekayaan, karena mengelola wakaf adalah kewajiban dari menjaga kelima unsur primer tersebut.

Mengelola wakaf tanah masjid berarti telah menjaga atau memelihara; 1) agama, karena pusat kegiatan agama yang efektif adalah di masjid; 2) dan 3) jiwa dan keturunan, karena dengan pengelolaan yang produktif maka masyarakat akan turut serta mengembangkan tanah wakaf agar dapat menghidupi dirinya sendiri dan keluarga agar selalu dalam keadaan sehat dan berumur panjang; 4) akal budi, karena dengan pengelolaan yang produktif dan efektif berarti turut serta mencerdaskan masyarakat dengan tidak hanya berpangku tangan tapi juga dapat berperan aktif dalam pengelolaan wakaf; 5) harta, karena dengan turut serta menghidupkan tanah wakaf masjid tersebut dalam kerangka produktif artinya perputaran ekonomi akan terus bergerak dan masyarakat akan menjadi sejahtera.

Adapun pengelolaan yang tidak efektif dapat dilihat dari dua petunjuk dasar yakni wakaf tanah masjid yang tidak terorganisir dan tidak bersertifikat, serta tidak terorganisir tapi bersertifikat. Sedangkan yang efektif dapat dilihat dari pengorganisasian yang baik dan bersertfikat, serta pengorganisasian yang baik meskipun tidak bersertifikat. Konsekuensi yang kedua ini diambil karena multi analisis, baik faktor lambatnya birokrasi sertifikasi atau memang surat penyerahan dari wakif yang bermaterai sudah dirasa cukup sehingga tidak dibutuhkan lagi sertifikat tanah wakaf.

\section{Relevansi UU Nomor 41 Tahun 2004 dalam Penerapan Hukum Wakaf Tanah Masjid di Kota Manado}

Umat Islam harus yakin bahwa Allah swt tidak menciptakan manusia, seperti juga tidak menciptakan jin, kecuali untuk beribadat kepada-Nya. Beribadat dalam arti mengabdi kepadaNya secara keseluruhan, baik seluruh sikap hidup dan kehidupan manusia secara pribadi, maupun sebagai anggota masyarakat dan sebagai kesatuan makhluk pada umumnya.

Pelaksanaan ibadat dipraktekkan dan dimanifestasikan melalui pengabdian keseluruhan diri manusia beserta segala apa yang dimilikinya. Satu bentuk ibadat melalui pengorbanan dengan harta yang kita miliki untuk kepentingan kemanusiaan, kemasyarakatan, dan keagamaan yang telah diatur oleh syari'at Islam adalah waqaf, dalam perundang-undangan Indonesia, dan seterusnya ditulis dengan kata wakaf.

Wakaf telah disyari'atkan dan telah dipraktekkan oleh umat Islam seluruh dunia sampai sekarang, termasuk oleh masyarakat Islam di negara Indonesia. "Menurut Ameer Ali, hukum wakaf merupakan cabang yang terpenting dalam syari'at Islam, sebab ia terjalin ke dalam seluruh kehidupan ibadat dan perekonomian sosial kaum muslimin"17.

Indonesia merupakan negara yang berfalsafah Pancasila. Dalam falsafah tersebut salah satu silanya adalah "Ketuhanan Yang Maha Esa". Dalam 
konstitusi negara Indonesia, yaitu Undang- Undang Dasar 1945 pada pasal 29 ayat 1 disebutkan, "Negara berdasar atas Ketuhanan Yang Maha Esa. Dengan demikian berarti bangsa Indonesia mengakui adanya Tuhan Yang Maha Esa dengan segala konsekwensinya".

Mengenai bagaimana konsepsi bangsa Indonesia tentang kekayaan alam di negaranya, disebutkan dalam pasal 33 ayat 3 UUD 1945, “.....bumi, air dan kekayaan alam yang terkandung di dalamnya dikuasai oleh Negara dan dipergunakan untuk sebesar-besar kemakmuran rakyat". Dalam UUPA (Undang-Undang Pokok Agraria, UU No. 5 Tahun 1960) yang merupakan undang-undang pelaksanaan dari basal 33 UUD 1945, pada bagian Menimbang huruf a, disebutkan antara lain, “....bumi, air dan ruang angkasa sebagai karunia Tuhan Yang Maha Esa". Dalam pasal 1 ayat 2 UU tersebut dinyatakan, ".....seluruh bumi, air dan ruang angkasa, termasuk kekayaan alam yang terkandung di dalamnya dalam wilayah Republik Indonesia sebagai karunia Tuhan Yang Maha Esa".

Menurut para ahli, lembaga sosial yang hampir sama dengan wakaf telah dikenal di Indonesia sebelum Islam datang ke negeri ini. Hal ini sebagaimana dikemukakan oleh Daud Ali :

"Sebelum Islam datang ke tanah air kita ini, telah ada suatu lembaga sosial yang kedudukannya hampir sama dengan wakaf. Untuk menyebut sekedar contoh dapat dikemukakan tanah perman di Lombok dan tanah pusaka (tinggi) di Minangkabau. Oleh karena itu dapat dipahami, kalau pengertian kaum muslimin di Indonesia tentang wakaf

18 Muhammad Daud Ali, Sistem Ekonomi Islam Zakat dan Wakaf (Jakarta: UI Press, 1988) h. 94

19 Abdurrahman, Masalah Perwakafan Tanah Milik dan Kedudukan Tanah Wakaf di Negara Kita (Bandung: Alumni, 1979) h. 14 selain didasarkan pada al-Qur'an, kitabkitab hadits dan kitab-kitab fikih terutama fikih Islam madzhab Syafi'i, juga oleh adat. Adat orang Islam Indonesia banyak yang berasal. dari atau dipengaruhi oleh ajaran Islam, termasuk di antaranya adat mengenai wakaf. Sebaliknya, lembaga keagamaan yang berasal dari ajaran Islam itu telah diwarnai pula oleh adat Indonesia terutama oleh prinsip adat kerukunan, kepatutan dan keselarasan dalam menyelesaikan perselisihan yang terjadi mengenai wakaf". ${ }^{18}$

Menurut Mr. Koesoema Atmadja bahwa lembaga wakaf (dengan nama: Vrome Stichtingen-pen.) sudah dikenal dalam masyarakat Indonesia sebelum datangnya agama Islam. ${ }^{19}$ Sedangkan menurut Ter Haar, "Lembaga Hukum Wakaf Islam ini telah diterima (gerecipereed) di banyak daerah Nusantara ini. dan yang disebut dengan istilah Belanda "Vrome Stichting"20. Resepsi wakaf dalam hukum adat tak mengherankan, karena sebagian besar bangsa Indonesia beragama Islam, "Inilah salah satu dari bagian hukum adat yang berasal dari agama (godsdienstig bestanddeel van het adatrecht)"21.

Pada tahun 1960, bangsa Indonesia telah berhasil membuat peraturan dasar pokok-pokok agraria yang merupakan peraturan dasar tentang pengaturan masalah agraria atau sumber alam tanah dengan segala isinya, termasuk ruang angkasa, yang tertuang dalam Undang-undang No. 5 Tahun 1960. Undang-undang ini terkenal dengan Undang-undang Pokok Agraria, disingkat UUPA. Dalam undang-

20 Ter Haar Bzn, Beginselen En Stelsel Van Het Adatrecht, Terjemahan K. Ng. Soebekti Poesponoto, (Jakarta: Pradnya Paramita, 1968) h. 136

${ }^{21}$ Ali Rido, Badan Hukum dan Kedudukan Badan Hukum Perseroan Perkumpulan Koperasi dan Wakaf (Bandung: Alumni, 1977) h. 132 
undang tersebut sudah dicantumkan tentang ketentuan pokok mengenai perwakafan tanah, yaitu dalarn pasai 49 ayat (3), “.....Perwakafan tanah milik dilindungi dan diatur dengan Peraturan Pemerintah".

Pada tahun 1977, telah dikeluarkan Peraturan Pemerintah seperti yang dikehendaki oleh pasal 49 ayat (3) UUPA tersebut di atas, yaitu Peraturan Pemerintah No. 28 Tahun 1977, tentang Perwakafan Tanah Milik. Setelah keluarnya PP No. 28 Tahun 1977, kemudian disusul dengan berbagai peraturan perundangan lainnya, seperti Peraturan Menteri Dalam Negeri No. 6 Tahun 1977 tentang Tata Pendaftaran Tanah mengenai Perwakafan Tanah Milik, dan peraturan pelaksanaan lainnya.

Tahapan terakhir dari keseluruhan proses pembentukan UU tentang wakaf adalah tahapan pengundangannya ke dalam suatu penerbitan sesuai dengan ketentuan perundang-undangan yang berlaku, yaitu ke dalam Lembaran Negara. UU ini disahkan oleh Presiden pertama yang dipilih secara langsung yakni Susilo Bambang Yudhoyono pada tanggal 27 Oktober 2004, seminggu setelah Presiden dilantik oleh MPR, yaitu pada tanggal 20 Oktober 2004. Pada tanggal 27 itulah UU ini diundangkan dan dicatat dalam Lembaran Negara Republik Indonesia tahun 2004 Nomor 159. Dalam UU ini wakaf diartikan sebagai "perbuatan hukum wakif untuk memisahkan sebagian benda milimnya, untuk dimanfaatkan selamnya atau dalam jangka waktu tertentu sesuai kepentingannya guna keperluan ibadah dan atau kesejahtraan umum menurut syari'ah." 22

Undang-undang ini mengandung tiga unsur, yaitu ; Pertama, memberikan kemungkinan kaum muslimin

22 Direktorat Pemberdayaan Wakaf dan Direktorat Jendral Bimbingan Masyarakat Islam, menjalankan syari'atnya dalam kegiatan ibadah wakaf. Artinya, memisahkan sebagian harta miliknya untuk dikekalkan yang manfaatnya untuk kepentingan umum. Kedua, dimensi hukum substansinya diarahkan adanya hukum positif mengatur wakaf dalam bentuk undang-undang. Dalam konteks hukum nasional, undang-undang ini merupakan unifikasi hukum wakaf. Seluruh kegiatan wakaf mulai dari rukun, wakif, nazir, harta benda yang diatur undang-undang ini bahkan terdapat lembaga secara khusus dibentuk yaitu Badan Wakaf Indonesia (BWI). Ketiga, dimensi kesejahtraan ekonomi dan kesejahtraan umat seperti wakaf uang merupakan terobosan berani dari pemerintah dan kejelian melihat peluang untuk dijadikan sumbangsih bagi kehidupan bermasyarakat, berbangsa dan beragama. Dari penjelasan ini maka jelaslah bahwa, undang-undang No. 41 tahun 2004 tentang wakaf merupakan wujud adanya pembaharuan hukum perwakafan di Indonesia, menegaskan adanya paradigma baru wakaf serta sebagai instrument hukum pengembangan dan pengelolaan tanah wakaf kearah produktif.

Berdasarkan petunjuk tersebut maka melalui teori terapan yakni almashlahah maka pencatatan atau sertifikasi wakaf terklasifikasi hukum wajib, sehingga apabila saat ini masih ada tanah atau barang-barang wakaf yang ikrar wakafnya belum dicatatkan, haruslah segera dicatatkan, karena pencatatan perbuatan hukum wakaf ini untuk memberikan perlindungan hukum dan kepastian hukum bagi wakif, nazhir dan harta yang diwakafkan.

Optimalisasi pengelolaan wakaf tanah masjid di Kota Manado harus didukung oleh program pemerintah

Proses Lahirnya Undang-Undang No.41 Tahun 2004 Tentang Wakaf, Jakarta, 2006, hlm. 247 
melalui Bimbingan Masyarakat Islam Kementerian Agama Kota Manado dengan melakukan pendataan tanah wakaf di KUA Kecamatan, sosialisasi dan bimbingan bagi PPAIW (Pejabat Pembuat Akta Ikrar Tanah) dan nazhir, memfasilitasi penyelesaian pensertifikatan wakaf tanah yang belum bersertifikat dengan bantuan anggaran dari DIPA Kantor Wilayah Kementerian Agama Provinsi Sulawesi Utara. Bersama-sama Seksi Bimas Islam melaksanakan pendataan, sosialisasi dan pembinaan kepada nazhir, PPAIW, dan Ormas Islam, menyelesaikan pensertifikatan tanah wakaf yang masih belum bersertifikat wakaf, kerja sama dalam melaksanakan pendataan tanah wakaf di KUA Kecamatan Se-kota Manado, koordinasi dengan KUA, Bimas Islam tentang data tanah wakaf yang akan disertifikatkan, melaksanakan kegiatan sosialisasi dan bimbingan.

Petunjuk di atas memberikan arahan bahwa pemerintah harus berperan aktif berdasarkan UU tentang Wakaf dalam upaya mengoptimalisasikan pengelolaan wakaf tanah masjid di Kota manado. Pentingnya regulasi hukum tentang wakaf tersebut yakni Pasal 4 dan pasal 5 yang menjelaskan bahwa wakaf bertujuan memanfaatkan harta benda wakaf sesuai dengan fungsinya; wakaf berfungsi mewujudkan potensi dan manfaat ekonomis harta benda wakaf untuk kepentingan ibadah dan untuk memajukan kesejahteraan umum.

Pasal 12 mengenai peruntukan harta benda wakaf yang menegaskan bahwa dalam rangka mencapai tujuan dan fungsi wakaf, harta benda wakaf hanya dapat diperuntukkan bagi: 1) sarana dan kegiatan ibadah; 2) sarana dan kegiatan pendidikan serta kesehatan; 3) bantuan kepada fakir

${ }^{23}$ Abdurrahman Kasdi, "Peran Pemerintah Dalam Regulasi Perundang-Undangan Wakaf", Jurnal ZISWAF, Vol. 2, No. 2, Desember 2015 miskin, anak terlantar, yatim piatu, beasiswa; 4) kemajuan dan peningkatan ekonomi umat; dan 5) kemajuan kesejahteraan umum lainnya yang tidak bertentangan dengan syariat dan peraturan perundang-undangan yang berlaku. $^{23}$

Atas dasar lahirnya Undangundang No. 41 tahun 2004 tentang Wakaf, artinya pemerintah berupaya memfokuskan perhatiaannya pada penataan administratif wakaf yang memberi kepastian hukum bagi wakif (pewakaf), nadzir (pengelola) dan maukuf 'alaih (obyek wakaf) serta mendorong pemanfaatan asset aset wakaf yang tidak produktif menjadi berdaya guna dan berhasil guna. Selain dari pada itu juga harus memfasilitasi penyelesaian pensertifikatan wakaf tanah yang belum bersertifikat dengan bantuan anggaran dari DIPA Kantor Wilayah Kementerian Agama Provinsi Sulawesi Utara. Bersama-sama Seksi Bimas Islam Melaksanakan pendataan, sosialisasi dan pembinaan kepada Nazhir, PPAIW, dan Ormas Islam.

Relevansi dari implementasi UU tersebut tentu akan mampu menjadikan wakaf tanah yang punya lahan untuk ditingkatkan menjadi wakaf produktif, seperti mengadakan gedung serba guna atau gedung pernikahan muslim. Hal ini perlu dikelola secara profesional, untuk itu tuntutan nazhir yang mempunyai kompetensi merupakan suatu yang urgen, di mana dapat memaksimalkan pengelolaan tanah wakaf sehingga menjadi produktif.

Selain daripada itu, berdasarkan ketentuan UU Wakaf, pencatatan perbuatan hukum wakaf diatur dalam ketentuan tentang ikrar wakaf, yakni bagian ketujuh Ikrar Wakaf sebagaimana pada; 
1. Pasal 17

a. Ikrar wakaf dilaksanakan oleh Wakif kepada Nazhir di hadapan PPAIW dengan disaksikan oleh 2 (dua) orang saksi.

b. Ikrar Wakaf sebagaimana dimaksud pada ayat (1) dinyatakan secara lisan dan/atau tulisan serta dituangkan dalam akta ikrar wakaf oleh PPAIW.

2. Pasal 18, dalam hal wakif tidak dapat menyatakan ikrar wakaf secara lisan atau tidak dapat hadir dalam pelaksanaan ikrar wakaf karena alasan yang dibenarkan oleh hukum, Wakif dapat menunjuk kuasanya dengan surat kuasa yang diperkuat oleh 2 (dua) orang saksi.

3. Pasal 19, untuk dapat melaksanakan ikrar wakaf, wakif atau kuasanya menyerahkan surat dan/atau bukti kepemilikan atas harta benda wakaf kepada PPAIW.

4. Pasal 20 Saksi, dalam ikrar wakaf harus memenuhi persyaratan: dewasa; beragama Islam; berakal sehat; tidak terhalang melakukan perbuatan hukum.

5. Pasal 21

a. Ikrar wakaf dituangkan dalam akta ikrar wakaf.

b. Akta ikrar wakaf sebagaimana dimaksud pada ayat (1) paling sedikit memuat: nama dan identitas Wakif; nama dan identitas Nazhir; data dan keterangan harta benda wakaf; peruntukan harta benda wakaf; jangka waktu wakaf

Adapun menurut ketentuan Pasal 6 Undang-undang No. 41 Tahun 2004 tentang Wakaf, wakaf dapat dilaksanakan apabila telah memenuhi unsur-unsur tentang wakaf, unsurunsur tersebut yaitu:

1. Adanya wakif

2. Adanya Nazhir
3. Adanya harta benda wakaf

4. Adanya ikrar wakaf

5. Peruntukan harta benda wakaf

6. Jangka waktu wakaf.

Unsur-unsur tersebut bersifat kumulatif artinya wakaf dapat dilaksanakan apabila semua unsurunsur tersebut terpenuhi, kalau tidak maka pelaksanaan wakaf batal secara hukum. Di kota Manado untuk menyelesaikan pensertifikatan tanah wakaf yang masih belum bersertifikat wakaf, maka dilakukan kerja sama dalam melaksanakan pendataan tanah wakaf di KUA Kecamatan Se-kota Manado, Koordinasi dengan KUA, Bimas Islam tentang data tanah wakaf yang akan disertifikatkan, melaksanakan kegiatan sosialisasi dan bimbingan.

Peran dari PPAIW sangat penting dalam penataan administrasi sertifikat wakaf setiap kecamatan yang ada di Kota Manado, tugas dan fungsi PPAIW adalah Mendata, mencatat wakaf, AIW (Akta Ikrar Wakaf), PPAIW untuk dikelola oleh Nazhir dan mendapat legalitas hukum. mendapatkan bukti kepemilikan tanah dengan sertifikat, mengesahkan Nazhir.

Peran PPAIW adalah untuk memperlancar proses hak kepemilikan status tanah wakaf, KUA sebagai PPAIW merekomendasikan ke BPN untuk pengurusan sertifikat. Proses pensertifikatan wakaf tanah adalah: Wakif datang ke KUA untuk mengikrarkan wakaf tanah dengan 2 orang saksi dan Nazhir yang ditunjuk, KUA membuat AIW dan APAIW serta pengesahan Nazhir, berkas yang sudah lengkap di teruskan Ke BPN Kota Manado. Proses pensertifikatan wakaf tanah adalah: memasukan data AIW ke BPN Kota Manado bersama Wakif dan Nazhir.

Dalam Pelaksanaan perwakafan tanah, calon/ Pihak yang hendak mewakafkan tanah harus datang di hadapan Pejabat pembuat Akta Ikrar Wakaf (PPAIW) untuk melaksanakan 
ikrar wakaf (Pasal 1 ayat 1 PP No 28 Tahun 1977) Untuk mewakafkan tanah hak milik calon wakif harus mengikrarkan secara lisan, jelas dan tegas kepada Nazhir yang telah diserahkan di hadapan PPAIW yang mewilayahi tanah wakaf dan dihadiri saksi-saksi dan selanjutnya menuangkannya dalam bentuk tertulis menurut bentuk W1. Sedangkan bagi mereka yang tidak mampu menyatakan kehendaknya secara lisan dapat menyatakan dengan isyarat. ${ }^{24}$

Pengikraran wakaf berarti menjadikan objek wakaf sebagai milik Tuhan yang harus dipakai semata-mata untuk tujuan keagamaan. Isi dan bentuk Ikrar Wakaf ditetapkan oleh Menteri Agama (Pasal 9 (3) PP 28 Tahun 1977. Bentuk dan isi ikrar wakaf telah ditentukan dalam peraturan Direktorat Jenderal Bimbingan Masyarakat Islam tanggal 18 April 1978 No.Kep/D/75/78.

Sedangkan bagi Calon Wakif yang tidak dapat datang di hadapan PPAIW dapat membuat ikrar wakaf secara tertulis dengan persetujuan Kandepag yang mewilayahi tanah wakaf serta diketahui saksi-saksi (Pasal 5 ayat 2 PP No. 28 Tahun 1977). Dalam pelaksanaan ikrar wakaf tanah ada dua macam akta ikrar wakaf pertama, akta ikrar wakaf dimana pelaksanaan wakaf tanah langsung dilakukan oleh pihak pemilik hak atas tanah dan yang kedua, akta ikrar wakaf pengganti yaitu pelaksanaan wakaf atas tanah dilakukan oleh pihak ahli waris dari pemilik tanah. Pada penjelasan Pasal 9 PP No 28 Tahun 1977 ditegaskan bahwa pasal ini mengharuskan adanya perwakafan dilakukan secara tertulis tidak cukup hanya dengan ikrar wakaf lisan saja. ${ }^{25}$

Tujuannya adalah untuk memperoleh bukti yang autentik yang

$24 \quad$ PP No. 28 Tahun 1977 tentang Perwakafan Tanah Milik Pasal 5 ayat 2 dapat dipergunakan untuk berbagai persoalan seperti untuk bahan pendaftaran pada Kantor Sub Direktorat Agraria Kabupaten/ Kotamadya dan untuk keperluan penyelesaian sengketa di kemudian hari tentang tanah yang telah diwakafkan. Bagi keperluan kelancaran dalam proses perwakafan seseorang yang hendak mewakafkan tanah harus membawa serta tandatanda bukti pemilikan berupa sertifikat / kitir tanah) dan surat-surat lain yang menjelaskan tidak adanya halangan untuk melakukan perwakafan atas tanah milik tersebut. Untuk keperluan tersebut maka diperlukan pejabatpejabat yang khusus melaksanakan pembuatan aktanya. ${ }^{26}$

Apabila akta ikrar wakaf telah dilaksanakan sesuai dengan ketentuan, maka Pejabat Pembuat Akta Ikrar Wakaf atas nama Nazhir yang bersangkutan, diharuskan mengajukan permohonan kepada Bupati/Walikota Kepala Daerah cq Kepala Sub Direktorat Agraria setempat untuk mendaftar perwakafan tanah milik yang bersangkutan menurut ketentuan Pasal 10 PP 28 Tahun 1977. Permohonan harus disampaikan selambat-lambatnya dalam jangka waktu 3 bulan sejak dibuatnya akta ikrar wakaf (Pasal 3 Permendagri No. 6 Tahun 1977. Bupati/ Walikota Kepala Daerah cq. Kepala Sub Direktorat Agraria setempat, setelah menerima permohonan tersebut dalam ayat 1 mencatat perwakafan tanah milik yang bersangkutan dalam buku tanah dan sertifikatnya.

Apabila tanah milik yang diwakafkan belum mempunyai sertifikat maka pencatatan yang dimaksud dilakukan setelah tanah tersebut dibuat sertifikatnya, setelah dilakukan pencatatan perwakafan tanah milik

${ }^{25}$ Zamakhsyari Dhofier, Tradisi Pesantren Studi Tentang Pandangan Hidup Kyai, (Jakarta: LP3S, 1994) h.102

26 Ibid 
dalam buku tanah dan sertifikatnya, maka Nazhir yang bersangkutan wajib melaporkan kepada orang yang mau mendaftarkannya, maka Kepala Desa tempat tanah tersebut harus mendaftarkannya kepada KUA setempat. Pelaksanaan Pendaftaran harus disertai

1. Surat keterangan tentang tanah atau surat keterangan Kepala Desa tentang perwakafan, tanah tersebut

2. Dua orang yang menyaksikan ikrar wakaf atau saksi-saksi istifadhah yang mengetahui atau mendengar tentang perwakafan).

Kepala KUA selaku Pejabat Pembuat Akta Ikrar Wakaf harus:

1. Meneliti keadaan tanah wakaf;

2. Meneliti dan mengesahkan Nazhir

3. Meneliti saksi-saksi

4. Menerima penyaksian tanah wakaf

5. Membuat akta pengganti akta ikrar wakaf

6. Membuat salinan akta pengganti akta ikrar wakaf

7. Menyampaikan akta pengganti ikrar wakaf lembar kedua kepada Bupati/ Walikotamadya Kepala Daerah cq Kepala sub Direktorat Agraria setempat sebagai lampiran permohonan pendaftaran

8. Mengirimkan akta pengganti akta ikrar wakaf lembar ke tiga kepada Pengadilan Agama yang mewilayahi tanah wakaf

9. Menyampaikan salinan akta pengganti akta ikrar wakaf lembar pertama kepada wakif atau ahli warisnya.

Biaya administrasi dan pencatatan tanah wakaf untuk penyelesaian administrasi perwakafan tanah di KUA Kecamatan termasuk formulir tidak dikenakan biaya, kecuali bea materi menurut ketentuan yang berlaku. Untuk penyelesaian pendaftaran dan perwakafan tanah di Kantor Sub. Direktorat Agraria tidak dikenakan biaya, kecuali biaya pengukuran dan biaya meterai menurut ketentuan yang berlaku. Pengaturan khusus akan masalah wakaf dalam UUPA dalam hal mengenai kewajiban-kewajiban pembentuk undang-undang untuk mengindahkan unsur-unsur yang berdasarkan pada hukum agama.

Dengan dikeluarkan Peraturan Pemerintah No. 38 Tahun 1963 tentang penunjukan badan-badan hukum yang dapat mempunyai hak milik atas tanah, diatur badan-badan hukum yang dapat memiliki tanah sebagai realisasi pasal 21 ayat 2 UUPA (Undang-Undang Pertanahan dan Agraria), ditegaskan penentuan mengenai tanah wakaf menjadi kompetensi Departemen Agraria dan Departemen Agama.

Berdasarkan ketentuan Pasal 17 sampai dengan Pasal 21 UU No. 41 Tahun 2004 tentang Wakaf, maka Penulis berpendapat bahwa pencatatan perbuatan hukum wakaf adalah wajib, sehingga apabila saat ini masih ada tanah atau barang-barang wakaf yang ikrar wakafnya belum dicatatkan, haruslah segera dicatatkan. Karena pencatatan perbuatan hokum wakaf ini untuk memberikan perlindungan hukum, dan kepastian hukum bagi wakif, Nazhir dan harta yang diwakafkan.

Jadi ketentuan-ketentuan berkaitan dengan pengurusan wakaf tanah masjid, yang masih banyak belum dilakukan oleh pembuatan akta ikrar wakaf, karena ada berbagai macam persyaratan yang harus dipenuhi. Hal ini sangat dibutuhkan dukungan dari pemerintah dalam hal ini Kementerian Agama Kota Manado untuk mengarahkan wakif dan Nazhir dalam mengurus status wakaf tanah masjid di Kota Manado.

Uraian di atas menegaskan bahwa dibentuknya Undang-undang Nomor 41 Tahun 2004 tentang wakaf, memiliki esensi utama yaitu:

1. Memajukan kesejahteraan umum. Untuk mencapai tujuan tersebut, 
diperlukan pengembangan dan penggalian potensi yang terdapat dalam pranata keagamaan yang memiliki manfaat ekonomis. Diantara langkah yang dipandang strategis untuk meningkatkan kesejahteraan umum adalah meningkatkan peran wakaf sebagai pranata keagamaan yang pada awalnya hanya berfungsi sebagai sarana ibadah dan sosial, menjadi pranata yang memiliki kekuatan ekonomi yang diyakini dapat memajukan kesejahteraan umum. Oleh sebab itu, penggalian potensi wakaf dan pengembangan pemanfaatannya sesuai dengan prinsip syariah merupakan keniscayaan. Seperti yang dikembangkan oleh Masjid AlMisbah di mana wakaf tanah masjid dijadikan sebagai lahan produktif yaitu membuat tempat-tempat usaha untuk disewakan. Hal ini memberikan kontribusi yang positif terhadap jamaah yang ada disekitar masjid Al-Misbah. Dana tersebut digunakan untuk pengembangan sarana ibadah dan juga digunakan untuk dana rutin seperti membayar rekening listrik.

2. Praktik wakaf yang ada sekarang di masyarakat belum sepenuhnya berjalan tertib dan efisien. Salah satu buktinya adalah diantara harta benda wakaf tidak terpelihara dengan baik, terlantar, bahkan beralih ketangan pihak ketiga dengan cara melawan hukum. Keterlantaran dan pengalihan benda wakaf ketangan pihak ketiga terjadi karena: (1) kelalaian atau ketidakmampuan nazhir dalam mengelola dan mengembangkan harta benda wakaf; (2) sikap masyarakat yang kurang peduli atau belum memahami status harta benda wakaf yang seharusnya dilindungi sebagai media untuk mencapai kesejahteraan umum sesuai dengan tujuan, fungsi, dan peruntukan wakaf. Dengan adanya peran pemerintah melalui Kantor Kementerian Agama Kota Manado pada Seksi Bimas Islam maka mulai melakukan pemetaan dan sosialisasi berkaitan dengan wakaf tanah masjid yang ada di Kota Manado. Dengan adanya Undang-Undang Nomor 41 Tahun 2004 tentang Wakaf berkeyakinan bahwa pembentukan Undang-Undang tentang Wakaf merupakan keniscayaan untuk pembangunan hukum nasional yang juga sebagai alat atau media untuk mencapai kesejahteraan umum. Untuk itu peran dari BWI Kota Manado harus lebih dioptimalkan, di mana terus melakukan pengawasan dan bimbingan pada setiap masjid di Kota Manado.

\section{Kesimpulan}

Berdasarkan uraian di atas, maka dapatlah ditarik kesimpulan pada penelitian ini, yakni:

1. Pengelolaan wakaf tanah masjid di Kota Manado terklasifikasi pada dua hal, yakni efektif dan tidak efektif. Namun yang tidak efektif lebih banyak dari yang efektif, hal ini disebabkan karena banyak pengurus masjid merasa bahwa proses pengurusan sertifikat sangat prosedural, sehingga mereka kesulitan untuk mengurus sertifikat tersebut. Selain daripada itu, masih banyak pula pengurus masjid yang tidak dapat membedakan tugas keimaman, takmir masjid dan nazhir, hal ini seringkali berimplikasi pada tumpang tindihnya pengurusan wakaf tanah masjid. Terakir, masih banyak tanah-tanah atau barangbarang wakaf yang perbuatan hukum wakafnya belum dicatatkan 
karena pengaruh paradigma lama di masyarakat.

2. Relevenasinya adalah, dengan berlakunya UU No. 41 Tahun 2004 tentang Wakaf, maka pencatatan perbuatan hukum wakaf menjadi wajib hukumnya. Hal ini dimaksudkan untuk memberikan perlindungan yang penting dalam Pencatatan Wakaf setelah Berlakunya hukum, dan kepastian hukum bagi wakif, Nazhir dan harta yang diwakafkan, serta menghindari munculnya sengketa wakaf di kemudian hari. Namun Undangundang Wakaf tersebut belum bisa dilaksanakan secara optimal, karena masih banyak masyarakat yang tidak memahami aturan-aturan dari undang-undang tersebut. Badan Wakaf Indonesia (BWI) Kota Manado belum maksimal menjalankan tugas dan fungsinya secara optimal, terutama memberikan sosialisasi dan pengawasan terhadap pelaksanaan wakaf tanah masjid di Kota Manado.

\section{DAFTAR PUSTAKA}

Abdurrahman, Masalah Perwakafan Tanah Milik dan Kedudukan Tanah Wakaf di Negara Kita, Bandung: Alumni, 1979

Ali, Muhammad Daud., Sistem Ekonomi Islam Zakat dan Wakaf , Jakarta: UI Press, 1988

al-Haitami, Ibnu Hajar., Tuhfah al-Muhtaj bi Syarh al-Manhaj, Cet. II, Beirut: Dar al-Kutub al-'Ilmiyah, 2005

Amirin, Tatang M., Menyusun Rencana Penelitian, Jakarta: Rajawali Press, 1986), Cet. I, h. 109

Bzn, Ter Haar., Beginselen En Stelsel Van Het Adatrecht, Terjemahan K. Ng.
Soebekti Poesponoto, Jakarta: Pradnya Paramita, 1968

Departemen Agama RI, Alqur'an dan Tafsirnya, Jakarta: Departemen Agama, 2012

Departemen Agama RI, Undang-Undang Wakaf dan Peraturan Pemerintah Tentang Pelaksanaannya, Jakarta: Departemen Agama RI, 2007

Dhofier, Zamakhsyari., Tradisi Pesantren Studi Tentang Pandangan Hidup Kyai, Jakarta: LP3S, 1994

Direktorat Pemberdayaan Wakaf dan Direktorat Jendral Bimbingan Masyarakat Islam, Proses Lahirnya Undang-Undang No.41 Tahun 2004 Tentang Wakaf, Jakarta, 2006

Fyzee, Asaf AA., Outline of Muhammadan Law, Jakarta: Tintamas, 1966

Hafidudin, Didin., dan Tanjung, Hendri., Manajemen Syari'ah Dalam Praktek, Jakarta: Gema Insani Press, 2003

Kasdi, Abdurrahman., "Peran Pemerintah Dalam Regulasi Perundang-Undangan Wakaf", Jurnal ZISWAF, Vol. 2, No. 2, Desember 2015

Moloeng, Lexi. J., Metode Penelitian Kuantatif, Bandung: Remaja Rosda Karya, 2002

Rido, Ali., Badan Hukum dan Kedudukan Badan Hukum Perseroan Perkumpulan Koperasi dan Wakaf, Bandung: Alumni, 1977

Sunggono, Bambang., Metode Penelitian Hukum, Jakarta: Raja Grafindo Persada, 2001 